\title{
Pengembangan Media Jurnal Karier untuk siswa MTsN
}

\author{
Pepi Nuroniah ${ }^{1}$, M. Ramli ${ }^{2}$, Triyono ${ }^{2}$ \\ ${ }^{1}$ Bimbingan dan Konseling-Universitas Pendidikan Indonesia \\ ${ }^{2}$ Bimbingan dan Konseling-Universitas Negeri Malang
}

\begin{tabular}{l}
\hline INFO ARTIKEL \\
\hline Riwayat Artikel: \\
Diterima: 09-05-2019 \\
Disetujui: $18-07-2019$ \\
\hline
\end{tabular}

\section{Kata kunci:}

media career journal; specialization decisions; MTs students; media jurnal karier; keputusan peminatan; siswa MTs

\footnotetext{
Alamat Korespondensi:

Pepi Nuroniah

Bimbingan dan Konseling

Universitas Pendidikan Indonesia

Jalan Dr. Setiabudi 229

E-mail: pepinuroniah@upi.edu
}

\begin{abstract}
ABSTRAK
Abstract: This study aims to develop Journal Career media as a medium in developing student decision-making ability in MTsN. The preferred method is the Borg \& Gall development model summarized into three sections (1) introduction study, (2) stage of media development, (3) stage of media test. The result of product development in Jurnal Karier media has fulfilled the aspect of acceptability, namely accuracy, usability, practicality and attractiveness. Expert test Guidance Counseling and counseling category is very feasible, media expert test very feasible category, guidance and counseling teachers category is very feasible, user test category is very feasible. Based on these results Jurnal Karier media is very feasible and can be used for student decision-making process.
\end{abstract}

\begin{abstract}
Abstrak: Penelitian ini bertujuan mengembangkan media Jurnal Karier sebagai media bimbingan karier dalam mengembangkan kemampuan pengambilan keputusan peminatan siswa MTs. Metode yang dipilih adalah model pengembangan Borg \& Gall yang diringkas menjadi tiga bagian (1) studi pendahuluan, (2) tahap pengembangan media, dan (3) tahap uji media. Hasil pengembangan produk berupa media jurnal karier sudah memenuhi aspek akseptibilitas, yaitu ketepatan, kegunaan, kepraktisan dan kemenarikan. Penilaian uji ahli BK berkategori sangat layak, uji ahli media berkategori sangat layak, uji pengguna guru berkategori sangat layak dan uji pengguna siswa berkategori sangat layak. Berdasarkan hasil tersebut, maka media jurnal karier sangat layak dan diterima untuk digunakan dalam pengembangan kemampuan pengambilan keputusan peminatan siswa.
\end{abstract}

Siswa MTs adalah remaja di masa eksplorasi karier yang melakukan peranannya untuk pembentukan karier (Super, 1980). Siswa di Indonesia memilih peminatan pada sekolah lanjutan. Peminatan adalah proses pengambilan keputusan oleh siswa tentang pemilihan mata pelajaran, bidang keahlian atau kompetensi keahlian yang didasarkan atas pemahaman diri dan peluang lingkungan yang berkesinambungan untuk mencapai perkembangan optimal (Permendikbud, 2014). Peminatan sebagai proses pengembangan karier yang melibatkan pilihan karier, gaya pengambilan keputusan, interaksi dalam peran kehidupan, nilai yang dimiliki, dan konsep diri tentang peran hidupnya (Herr, Cramer, \& Niles, 2004). Menurut super karier memiliki jenjang (Super, 1980), sedangkan karier yang dijelaskan oleh Holland dipengaruhi oleh tipe karakteristik individu (Holland, 1997).

Siswa ada pada masa eksplorasi karier dan mulai belajar mengambil keputusan. Pengambilan keputusan bagian dari aspek kognitif yang menekankan pada pengeolahan informasi, pemahaman pengambilan keputusan dan keterampilan dalam mengambil keputusan (Sharf, 1992). Proses pengembilan keputusan terbagi menjadi tiga bagian yaitu domain pengetahuan, keterampilan dan eksekutif (Sampson, Peterson, Lenz, \& Reardon, 1992). Domain pengetahuan terdiri dari pengetahuan diri dan pengetahuan tentang pemilihan peminatan. Pengetahuan diri merupakan komponen yang memungkinkan individu untuk memahami keadaan dirinya. Pengetahuan tentang pilihan karier (peminatan) merupakan komponen di luar dirinya yang memungkinkan individu untuk mengakses berbagai informasi terkait dengan spesifikasi dan klasifikasi karier, sedangkan domain keterampilan terdiri dari komunikasi, analisis, sintesis, penilaian, dan pelaksanaan keputusan. Domain ketiga adalah domain eksekutif yang memungkinkan individu untuk melakukan wicara diri, penyadaran diri, serta adanya pantauan dan pengendalian pada diri individu berkenaan dengan proses pada kedua domain sebelumnya yaitu pengetahuan dan keterampilan dalam rangka pengambilan keputusan pemilihan peminatan (Hanggara, 2016).

Siswa di Indonesia dalam pengambilan keputusan tidak lepas dari pertimbangan keluarga. Siswa hidup, berkembang, dan berubah tidak lepas dari struktur dan pengaruh keluarga (Hambali, 2016). Diperlukan diskusi antara pilihan orangtua dan siswa terhadap peminatan. Siswa harus mengugkapkan kepada orangtua, keinginan, minat, ide, perasaan dan pilihan peminatan. Pengungkapkan diri adalah kemampuan seseorang dalam mengungkapkan apa yang dirasakan, ide dan pendapatnya yang 
berupa informasi tentang dirinya secara akurat kepada orang lain untuk mencapai hubungan yang akrab (Johnson, 1997). Tujuannya agar pemilihan peminatan berjalan dengan baik. Proses pengambilan keputusan yang tepat berdasarkan kesepakatan siswa dan orangtua menjadikan siswa lebih menikmati pembelajaran di sekolah (Marlina, Arifin Ahmad, \& Pandang, 2015). Ketepatan peminatan juga membantu siswa dalam pemutusan karier yang ingin dituju di masa depan. Semakin dini siswa mulai berlatih untuk mengambil keputusan semakin tepat keputusan yang dipilihnya sesuai dengan minat dan keterampilan yang dimiliki. Pilihan peminatan di sekolah menengah atas dilakukan pada jenjang sekolah menengah pertama memberikan kontribusi besar dalam perjalanan pendidikan dan karier individu selanjutnya (Musfirah, 2015).

Kendala dalam pengambilan keputusan yaitu belum mengenal kemampuan yang dimiliki, bingung menentukan pilihan, tidak mengetahui informasi pemintan, tidak mampu mengungkapkan tentang dirinya pada orangtua, tidak menyadari kesesuain minat, kemampuan, peluang dan kurang terampil dalam membuat keputusan yang dimiliki. Temuan di lapangan menunjukan banyaknya orangtua yang memaksakan anaknya untuk masuk ke kelompok peminatan Ilmu Pengetahuan Alam, sedangkan minat anaknya tidak di kelompok peminatan Ilmu Pengetahuan Alam. Hambatan lainnya hasil tes intelgensi kecenderungan untuk masuk peminatan Ilmu Pengetahuan Sosial, sedangkan minatnya pada bahasa (Dewi \& Nuryono, 2013).

Hasil wawancara yang dilakukan peneliti pada tanggal 26 Oktober 2017 terhadap guru bimbingan dan konseling di MTs Negeri 1 Malang. Permasalahan yang dihadapi dalam pemilihan peminatan adalah perbedaan keinginan siswa dan orangtua dikarenakan siswa belum memutuskan peminatan yang diinginkannya dan pengungkapan yang kurang tepat pada orangtua. Peneliti juga menyebarkan skala untuk mengetahui tingkat kemampuan pengambilan keputusan peminatan kepada 57 siswa kelas VIII MTs N 1 Malang. Hasilnya menunjukkan 2\% atau satu siswa memiliki tingkat kemampuan pengambilan keputusan peminatan dalam kategori sangat tinggi, $63 \%$ atau 36 siswa ada pada kategori sedang, dan $35 \%$ atau 20 siswa dalam kategori rendah.

Hasil lainnya berdasarkan wawancara, yaitu tiga siswa mengetahui minat dan bakatnya, namun belum yakin dengan pilihannya dikarenakan masih inkonsistensi dalam pilihannya, satu siswa memahami arah minatnya, tetapi berbeda dengan keinginan orangtua dan siswa lainnya belum mengetahui minat dan karier yang ingin ditujunya. Guru BK sebagai pembimbing berfungsi untuk melatih potensi secara optimal sesuai dengan tugas perkembangannya. Potensi yang dimaksud adalah pengambilan keputusan peminatan yang berkaitan dengan persiapan karier (Triyono, et al., 2016). Tujuannya siswa terbiasa mengambil keputusan sesuai dengan minat, bakat, kemampuan akademik dan hasil keputusannya dikomunikasikan pada orangtua.

Tugas guru BK dalam mengembangkan potensi siswa dibantu dengan penggunaan media untuk mempermudah pencapain tujuan. Media yang digunakan dalam layanan bimbingan dan konseling bertujuan untuk meningkatkan potensi peserta didik. Contohnya media permainan simulasi ular tangga yang efektif meningkatkan tanggungjawab belajar siswa SMA (Putri \& Ramli, 2016). Peneliti melakukan observasi dan wawancara pada guru BK MTsN 1 Malang media yang digunakan dalam bimbingan karier, belum ada media untuk informasi pemitan selain berupa banner pohon karier.

Peneliti hendak mengembangkan media yang berbentuk buku catatan harian yang diberi nama Jurnal Karier disingkat jurier. Media jurnal karier berfungsi sebagai panduan siswa dalam proses pengambilan keputusan peminatan. Media jurnal karier bertujauan untuk menjadi media yang membantu siswa memilih peminatan secara mandiri melalui proses pengambilan keputusan (Sampson et al., 2014). Media jurnal karier diterapkan dalam setting bimbingan kelompok yang memiliki empat tahapan, yakni (1) mendeskripsikan maksud dan misi tugas, (2) terlibat dalam kegiatan jurnal, (3) memeriksa kemajuan siswa dan melibatkannya dalam pertukaran yang bermakna yang berasal dari isi dan proses jurnal, dan (4) menyemangati siswa memodifikasi kegiatan bilamana dianggap perlu (Erford, 2015).

Media jurnal karier mengarahkan peserta untuk mengkonstruk pengetahuan dirinya, keinginannya, minat dan bakatnya agar dengan cara menarasikan dirinya agar mampu memilih peminatan yang sesui dengan apa yang diharapkannya (Savickas et al., 2009). Subjek penelitian adalah siswa MTs 1 Malang. Berdasarkan observasi siswa memiliki minat yang tinggi untuk memilih peminatan di sekolah lanjutan. Karateristik unik MTs yang bertempat di tengah-tengah kota dan sebaran data siswa merupakan siswa yang berasal dari keluarga perkotaan memiliki kecenderungan untuk melanjutkan studi yang diawali dengan peminatan. Berdasarkan hal tersebut, peneliti mengembangkan media jurnal karier untuk siswa MTs.

\section{METODE}

Model penelitian dan pengembangan ini menggunakan model adaptasi dari prosedur rancangan penelitian pengembangan Borg \& Gall yang memiliki sepuluh langkah pelaksanaan strategi penelitian dan pengembangan, yakni (1) penelitian dan pengumpulan data, (2) perencanaan, (3) pengembangan draft dan produk, (4) uji coba lapangan awal, (5) merevisi hasil uji coba, (6) uji coba lapangan, (7) penyempurnaan produk hasil uji lapangan, (8) uji pelaksanaan lapangan, (9) penyempurnaan produk akhir, dan (10) diseminasi dan implementasi (Gall, Gall, \& Borg, 2006).

Prosedur penelitian yang diadaptasi dari model penelitian dan pengembangan Borg \& Gall, penerapannya disesuaikan dengan kebutuhan penelitian. Langkah-langkah penelitian dan pengembangan yaitu (1) studi pendahuluan yang meliputi (a) analisis kebutuhan dilakukan dengan cara mengedarkan angket, skala kemampuan keputusan kepada siswa dan melakukan wawancara dengan guru BK, (b) studi kepustakaan yang dimaksudkan untuk mengkaji konsep dan dasar teoritik dalam mendukung asumsi penelitian, (c) penentuan subjek penelitian didasarkan pada karakteristik dan tugas perkembangan yang sedang dilalui oleh siswa yaitu kelas VIII, (d) persiapan bahan yang diperlukan, (2) tahap pengembangan media terdiri dari (a) 
deskripsi produk produk (b) penyusunan media jurnal karier, (c) penentuan desain panduan, (3) tahap uji media yaitu (a) uji validasi yang dilakukan oleh ahli bimbingan konseling dan uji ahli media oleh dosen Teknologi Pendidikan Universitas Negeri Malang, (b) uji pengguna yakni guru BK MTsN kota Malang dan tujuh siswa MTsN, (c) revisi dan penyempurnaan.

Jenis data yaitu data kuantitatif dan kualitatif. Data diperoleh dari hasil skala penilaian yang diberikan oleh uji ahli (media dan materi), calon pengguna dan kelompok kecil. Kedua data digunakan sebagai bahan pertimbangan untuk merevisi produk yang dikembangkan. Teknik analisis data yang adigunakan untuk kuantitatif dihitung menggunakan teknik penskoran analisis kuantitatif deskriptif dan analisis data kualitatif dianalisis melalui analisis kualitatif deskriptif, yaitu memaparkan data secara nyata. Statistik deskriptif digunakan untuk mengolah skor penilaian uji ahli dan uji pengguna rumus persentase sebagai berikut:

$$
\text { Persentase nilai rata-rata }=\frac{\sum \text { skor perolehan }}{\sum \text { skor maksimal }} \times 100
$$

Berdasarkan perolahan nilai total dan persentase nilai rata-rata yang telah diperoleh selanjutnya hasil analisis dimaknai berdasarkan kriteria pada tabel 1.

Tabel 1. Intrepretasi Validitas Uji Ahli dan Uji Pengguna

\begin{tabular}{lll}
\hline \multicolumn{1}{c}{ Skor } & Persentase & \multicolumn{1}{c}{ Makna/Interpretasi } \\
\hline $3.4-4$ & $85-100 \%$ & Sangat tepat/ sangat berguna/ sangat praktis/ sangat menarik/ sangat layak \\
\hline $2.6-3.3$ & $75-84 \%$ & Tepat/ berguna/ praktis/ menarik/ layak \\
\hline $1.9-2.5$ & $56-74 \%$ & Cukup tepat/ cukup berguna/ cukup praktis/ cukup menarik/ cukup layak \\
\hline $1-1.8$ & $\leq 55 \%$ & Tidak tepat/ tidak berguna/ tidak praktis/ tidak menarik/ tidak layak \\
\hline
\end{tabular}

\section{HASIL}

Hasil penelitian dan pengembangan adalah media jurnal karier untuk meningkatkan kemampuan pengambilan keputusan peminatan siswa MTs. Media berupa buku harian yang memiliki bagian (1) pencitraan diri siswa, (2) petunjuk penggunaan, manfaat dan cerita untuk mengawali bagian laiannya, (3) pengetahuan diri, (4) informasi peminatan, (5) wicara diri, (6) kesadaran diri dan pengungkapan diri pada orangtua. Setiap bagian tema berisikan pertanyaan, permintaan, cerita, dan kolom jeda atau refleksi untuk memacu siswa menceritakan dirinya sebagai arahan pada pengambilan keputusan peminatan yang akan dipilihnya. Bagian pengungkapan diri, siswa diminta untuk menceritakan keputusan peminatan yang dipilihnya pada orangtua. Di akhir lembaran jurnal karier, yakni refleksi kesan, pesan, dan rencana lanjutan yang harus dilaksanakan siswa.

Penerapan media jurnal karier dilaksanakan melalui setting bimbingan kelompok. Langkah-langkah pelaksanaannya yaitu (1) pertemuan I, guru BK pada pertemuan pertama melaksanakan pretest untuk mengetahui tingkat kemampuan pengambilan keputusan siswa, (2) pertemuan II, penerapan media jurnal karier dengan kegiatan pengenalan media jurnal karier dan penceritaan awal diri dalam setting bimbingan kelompok (3) pertemuan III, penerapan media jurnal karier dengan kegiatan evualuasi komitmen pada pertemuan sebelumnya dan penceritaan mengenal diri. Pemberian tugas untuk pertemuan selanjutnya pengisian pengenalan karakter, (4) pertemuan IV, penerapan media jurnal karier dengan pembahasan penceritaan pengenalan karakter diri dan penugasan pencarian informasi peminatan dan sekolah lanjutan, (5) pertemuan V, penerapan media jurnal karier dengan pembahasan penceritaan pencarian informasi peminatan, sekolah lanjutan dan mulai melakukan wicara diri secara bersama-sama. Pemberian tugas untuk pertemuan selanjutnya yakni pengisian lembar kesadaran diri dan mengungkapkannya pada orangtua, (6) pertemuan VI, penerapan media jurnal karir dengan pembahasan penceritaan kesadaran diri dan hasil pengungkapan diri pada orangtua. Pertemuan ini adalah akhir dari kegiatan penerapan jurnal karier, (7) pertemuan VII, guru BK melaksanakan posttest untuk mengetahui hasil dari penerapan media jurnal karier, yakni peningkatan kemampuan pengambilan keputusan siswa.

Langakah-langkah penerapan media jurnal karier disusun dalam buku panduan penggunaan media jurnal karier yang berisikan (1) pendahuluan yang memuat rasional, tujuan dan manfaat media jurnal karier, (2) konsep kunci yakni pengertian bimbingan kelompok, pengertian media jurnal karier dan karakteristik siswa MTs, (3) langkah penerapan media jurnal karier yakni tahapan bimbingan kelompok, langkah-langkah penerapan media jurnal karier, peran konselor dan konseli, (4) prosedur perlakuan yakni sasaran dan jadwal pelaksanaan, (5) penyususnan RPLBK (Rencana Pelaksanaan Layanan Bimbingan dan Konseling) (6) evaluasi, evaluasi pelaksanaan jurnal karier, saran balikan, catatan perkembangan siswa, lembar refleksi untuk konselor dan perencanaan untuk layanan bimbingan dan konseling selanjutnya, (7) penutup.

\section{Media Jurnal Karier}

Berdasarkan hasil uji validasi ahli BK, uji ahli media, dan pengguna media jurnal karier sangat layak digunakan sebagai media pengembangan keputusan peminatan siswa MTsN atau media bimbingan karier. Aspek kelayakan atau akseptibilitas melingkupi empat aspek, yakni ketepatan, kegunaan, kepraktisan, dan kemenarikan. Pemaparan hasil secara lengkap pada tabel 2 . 
Tabel 2. Penilaian Ahli dan Pengguna terhadap Media Jurnal Karier

\begin{tabular}{clccccc}
\hline No & Aspek & Ahli BK (\%) & Ahli Media (\%) & Guru BK (\%) & Siswa (\%) & Rata-rata (\%) \\
\hline 1 & Ketepatan & $96.9 \%$ & $93.8 \%$ & 92.2 & $90 \%$ & $93.3 \%$ \\
\hline 2 & Kegunaan & $100 \%$ & $96.2 \%$ & 96.2 & $88 \%$ & $95.1 \%$ \\
\hline 3 & Kepraktisan & $100 \%$ & $94.2 \%$ & 88.5 & $84 \%$ & $91.6 \%$ \\
\hline 4 & Kemenarikan & $97.9 \%$ & $93.8 \%$ & 95.8 & $85 \%$ & $93.0 \%$ \\
\hline & Rata-rata & $98.7 \%$ & $94.5 \%$ & $93.2 \%$ & $87 \%$ & $93.2 \%$ \\
\hline
\end{tabular}

Berdasarkan tabel 2 dapat disimpulkan media jurnal karier ada pada kategori sangat tepat, sangat berguna, sangat praktis dan sangat menarak maka media junal karier layak dan siap untuk digunakan sebagai media bimbingan karier khususnya pengambilan peminatan siswa MTsN.

Revisi produk dari uji ahli BK yakni typo, kesesuaian warna dasar dengan warna huruf dan pemilihan kata pertanyaan. Saran dari uji ahli bahwa media jurnal karier sangat layak digunakan dan cocok untuk anak muda, namun pewarnaan harus dipertajam atau dikontraskan. Guru BK memberikan saran untuk tambahan tabel akademik, non akademik, hobi, dan minat. Tujuan penambahan untuk kelengkapan data menuju sekolah lanjutan dan pelaksanaan peminatan karena bagian dari syarat peminatan. Berdasarkan pendapat dan komentar dari siswa media jurnal karier sangat baik dan dapat menjadi media untuk menyampaikan keinginan siswa dengan orangtua. Tujuh siswa menyatakan hal serupa dengan penyampaian yang berbeda.

Uji coba penerapan media jurnal karier juga dilakukan pada tahap ini yakni siswa mengisi dan menjawab pertanyaan yang ada pada media. Hasil uji coba media jurnal karier dapat membuat siswa mengenal tentang keinginan dan rencana karier tujuannya. Siswa juga mengetahui bahwa dirinya masih belum tahu tujuan peminatan yang diinginkannya.

\section{Buku Panduan Penggunaan Media Jurnal Karier}

Berdasarkan hasil uji validasi ahli bimbingan dan konseling, uji ahli media, dan guru bimbingan dan konseling secara umum buku panduan penggunaan media jurnal karier sangat layak digunakan. Buku panduan mememuhi aspek keberterimaan dengan hasil persentase $97 \%$ dengan kriteria sangat layak. Penguji tidak memberikan saran untuk perbaikan buku panduan penggunaan media jurnal karier kecuali typo. Hasil uji ahli media persentase $97.8 \%$ dengan kriteria sangat layak. Buku panduan media jurnal karier memiliki kriteria sangat layak dan dipertajam dalam pewarnaan. Buku panduan disimpulkan sangat layak digunakan untuk uji coba pengguna pada guru BK di MTsN 1 Malang. Buku panduan penggunaan media jurnal karier diujicobakan pada pengguna. Hasil uji pengguna dengan hasil persentase $89 \%$ dengan kriteria sangat layak. Tidak ada revisi dalam buku panduan penggunaan media jurnal karier. Tujuan pembuatan buku panduan untuk memmudahkan dalam penerapan media jurnal karier dan memantau perkembangan siswa.

\section{PEMBAHASAN}

Data yang didapatkan dari dari uji validasi tidak hanya berupa skor penilaian keberterimaan atau kelayakan media jurnal karier dan buku panduannya, namun juga berupa data kualitatif yakni saran, komentar, dan jawaban dalam media jurnal karier. Saran dan komentar bertujuan untuk memperoleh kesusain media jurnal karier dengan kelayakannya ditinjau dari teori dan kebutuhan siswa. Media jurnal karier tepat digunakan dan menarik bagi siswa menulis rencana karir dalam media jurnal karier.

Uji validasi dimaksudkan untuk memenuhi syarat keberterimaan, yakni ketepatan, kegunaan, kepraktisan, dan kemenarikan. Keberterimaan suatu media dinilai dari kesesuaian teori, isi dan tujuan yang disajikan dalam sebuah media berdasarkan teori konstruktivis, teori naratif, teori pengambilan keputusan karier dan setting penggunaan bimbingan kelompok. Hasil data dari uji ahli BK memiliki kriteria sangat tepat, sangat berguna, sangat praktis, dan sangat menarik sehingga dapat dikatakan memenuhi aspek keberterimaan secara teori. Media yang didasarkan pada teori naratif memiliki keberterimaan yang tinngi sebagaimana penelitian terdahulu yaitu media letter shering untuk meningkatkan keterampilan komunikasi siswa introvert (Afifah, Triyono, \& Hotifah, 2016).

Penilaian uji pengguna dilakukan setelah uji validitas. Hasil uji pengguna bertujuan untuk memenuhi persyaratan akseptibilatas dari segi praktik. Apek ketepatan pada media jurnal karier adalah ketepatan antara isi media jurnal karier dengan tujuan, meteri, bahasa dan tata cara penggunaan media secara teori maupun praktik. Hasil penilaian uji ahli untuk aspek ketepatan kategori sangat tepat ditinjau dari teori dan dilakukan revisi. Hasil uji pengguna guru dan siswa kategori sangat tepat. Penilaian baik dari uji ahli secara teori dan uji pengguna secara praktik menunjukkan hasil yang signifikan, yakni kategori sangat tepat.

Kategori dihasilkan sangat tepat dikarenakan dalam penyusunannya, peneliti sangat memerhatikan pertanyaan, permintaan, dan pendukungnya disesuaikan dengan teori yang dipilih. Pemilihan pertanyaan dan permintaan yang memancing siswa untuk bercerita tentang dirinya. Terinspirasi dari pertanyaan-pertanyan naratif Savickas (Savickas, et al., 2009). Pertanyaan ada dalam buku panduan My Career Story (Hartung \& Santilli, 2018). Kisah karir menggambarkan konsep unik individu yaitu kepribadian dari sudut pandang mereka sendiri (Savickas, 2014) . 
Aspek kegunaan pada media jurnal karier adalah kebermanfaatan media untuk mencapai tujuan layanan bimbingan karier yaitu peningkatan kemampuan pengambilan keputusan peminatan siswa. Kegunaan dinilai dari setiap pertanyaan, permintaan, cerita, gambar, sinopsis film dalam media jurnal karier. Hasil penilaian uji ahli untuk aspek kegunaan kategori sangat berguna ditinjau dari teori dan tidak ada revisi dalam aspek. Hasil uji pengguna guru BK kategori sangat berguna namun ada kolom yang perlu ditambah seperti kolom keberhasilan dalam bidang akademik dan non-akademik serta penghapusan peminatan IIS dan MIA karena sama dengan MIPA dan IPS. Hasil uji pengguna siswa atau kelomok kecil kategori sangat berguna. Media jurnal karier kategori sangat berguna karena sesuai dengan penelitian studi kasus yang dilakukan Savicks menggunakan pertanyaan dan permintaan naratif dapat membuat seorang individu menemukan konsep diri yang dikonstruk oleh dirinya sendiri (Savickas, 2014).

Pemberian sinopsis film, cerita dan gambar untuk merangsang kognitif siswa dalam mengidentifikasi kemiripan karakter tokoh, meningkatkan minat dan pemodelan dirinya dengan tokoh tersebut karena siswa tidak lepas dari cerita (Savickas, 2013). Cerita dari media film efektif meningkatkan minat dan hasil belajar (Yasri \& Mulyani, 2016). Media film dalam jurnal karier adalah sinopsis film yang sebelum penyajian tersebut diawali pertanyaan pengetahuan siswa tentang film (Auliyah \& Flurentin, 2016). Secara implisit, media film ada dalam jurnal karier. Kegunaan menulis buku harian memimiliki manfaat penurunan emosi negatif dan meningkatkan emosi positif dan meningkatkan well-being peserta penulisan (Chang, Huang, \& Lin, 2013).

Aspek keparaktisan pada media jurnal karier adalah kemudahan dan efektivitas waktu yang digunakan untuk mengisi media jurnal karier. Hasil penilain uji ahli dan uji pengguna guru BK sangat praktis sehingga tidak ada revisi dalam aspek kepraktisan. Hasil uji pengguna siswa praktis. Berbeda dengan hasil dari siswa yang menyatakan praktis karena satu siswa lebih menyukai ukuran buku lebih kecil, seperti buku saku pramuka, sedangkan tujuh siswa lain menyatakan ukuran tersebut sudah praktis. Kepraktisan dapat dilihat dari kemudadahan dalam proses penggunaannya (Alfiriani \& Hutabri, 2017). Media jurnal karier ukuran dengan buku tulis yakni A5 ketebalannya 100 halaman sehingga dapat dimasukan dalam tas sekolah atau dibawa oleh tangan karena tidak terlalu besar dan ringan. Tidak ada revisi untuk aspek kepraktisan karena uji penggunaan media jurnal karier. Setiap satu pertanyaan menghabiskan waktu sekitar lima menit untuk uraian cerita dari siswa. Kalkulasi waktu tersebut sesui dengan RPLBK yang ada dalam buku panduan. Setiap pertemuan memiliki waktu 45 menit maka $4-5$ pertanyaan dapat dijawab dan diikuti diskusi atau sharing antara guru BK dan siswa. siswa dapat mengisi media jurnal karier di luar jam sekolah karena pertanyaan dan permintaan sangat mudah untuk diisi.

Aspek kemenarikan adalah media jurnal karier menarik dari sudut pandang siswa. Siswa tidak bosan untuk mengisi media jurnal karier karena berisi cerita, gambar, kolom, tabel, quotes. Hasil dari uji ahli, guru BK dan siswa menyatakan sangat menarik. Hasil dikarenakan dengan media buku bergambar pemberian informasi karier efektif untuk meningkatkan pemahaman siswa pada masa remaja (Dahlan, 2015). Pemilihan warna dikarenakan memengaruhi short term memory siswa (Sujarwo \& Oktaviana, 2017). Media jurnal karier baik dari teoritik maupun praktik sangat menarik untuk siswa MTs sehingga dapat digunakan untuk mengembangkan kemampuan pengambilan keputusan peminatan.

Berdasarkan hasil validasi dapat disimpulkan media jurnal karier dikatakan layak secara teori. Media jurnal karier diterima dan dapat digunakan sebagai media bimbingan karier untuk membantu siswa dalam mengembangkan kemampuan keputusan peminatan. Hasil uji validitas menunjukkan nilai yang tinggi, meskipun demikian uji ahli memberikan saran untuk dilakukannya revisi guna perbaikan dari kekurangan media yang dikembangkan. Revisi yang disarankan merupakan dari aspek ketepatan yakni padanan pemilihan kata tanya dan aspek kemenarikan dari kesesuaian warna font dan background. Buku panduan penggunaan media jurnal karier sudah divalidasi oleh uji ahli. Buku panduana mememuhi aspek keberterimaan. Tidak ada revisi dalam buku panduan penggunaan media jurnal karier. Tujuan pembuatan buku panduan untuk mempermudah guru BK dalam menerapkan media jurnal karier dan memantau perkembangan siswa.

\section{SIMPULAN}

Penelitian pengembangan ini, hasilnya dapat disimpulkan sebagai berikut. Pertama, media jurnal karier dan buku panduan penggunaan media jurnal karier memiliki kualifikasi sangat layak dan siap digunakan. Kedua, media ini memiliki spesifikasi langkah-langkah pengambilan keputusan dimulai dari pengetahuan diri, pengetahuan informasi peminatan, keterampilan keputusan, kesadaran diri, wicara diri dan eksekusi pengambilan keputusan. Guru dapat mengetahui keputusan yang dipilih siswa pada kolom "keputusanku". Ketiga, buku panduan penggunaan media jurnal karier ntuk guru BK yang berisikan rasionalisasi media jurnal karier dan penerapannya melalui RPLBK, evaluasi uraian, dan soal pretest serta posttest, dan lembar refleksi bagi guru BK.

Pemanfaatan media jurnal karier sesuai dengan tujuan bimbingan dan konseling, khususnya di bidang layanan bimbingan karier. Guru BK mengikuti langkah-langkah dalam buku panduan penggunaan media jurnal karier. Guru BK harus memahami media jurnal karier dengan membacanya secara keseluruhan. Media jurnal karier sebelum disebar dan dimanfaatkan secara luas, perlu mengikuti tahapan Borg \& Gall secara keseluruhan sampai tahap diseminasi. Produk ini terbatas diujicobakan pada siswa MTsN 1 kota Malang. 


\section{DAFTAR RUJUKAN}

Afifah, E. I., Triyono, \& Hotifah, Y. (2016). Pengembangan Media Letter Sharing untuk Meningkatkan Keterampilan Komunikasi Siswa Introvert. Jurnal Kajian Bimbingan dan Konseling, 1(1), 27-32.

Alfiriani, A., \& Hutabri, E. (2017). Kepraktisan dan Keefektifan Modul Pembelajaran Bilingual Berbasis Komputer. Jurnal Kependidikan, 1(1), 12-23. Retrieved from https://media.neliti.com/media/publications/113371-ID-practicality-andeffectiviness-of-biling.pdf

Auliyah, A., \& Flurentin, E. (2016). Efektivitas Penggunaan Media Film untuk Meningkatkan Empati Siswa Kelas VII SMP. Jurnal Kajian Bimbingan dan Konseling, 1(2), 19-26. https://doi.org/10.17977/um001v1i12016p019

Chang, J. H., Huang, C. L., \& Lin, Y. C. (2013). The Psychological Displacement Paradigm in Diary-Writing (PDPD) and its Psychological Benefits. Journal of Happiness Studies, 14(1), 155-167. https://doi.org/10.1007/s10902-012-9321-y

Dahlan, N. (2015). Efektivitas Informasi Karir dengan Media Buku Bergambar untuk Meningkatkan Pemahaman Studi Lanjutan Siswa. Jurnal Psikologi Pendidikan dan Konseling: Jurnal Kajian Psikologi Pendidikan dan Bimbingan Konseling, 1(1), 77-83. https://doi.org/10.26858/kk.v1i1.1536

Dewi, F. Y., \& Nuryono, W. (2013). Survei Tentang Hambatan-Hambatan Selama Proses Peminatan (Dalam Konteks BK) Berdasarkan Kurikulum 2013 bagi Siswa di SMA Negeri se-Kota Surabaya. Journal of Chemical Information and Modeling, 53(9), 1689-1699. https://doi.org/10.1017/CBO9781107415324.004

Gall, M. D., Gall, J. P., \& Borg, W. R. (2006). Educational Research: An Introduction, 8th Edition. Educational An Introduction.

Hambali, I. (2016). Perspektif “Family System Intervency” untuk Proteksi Karakter Kebajikan Siswa SMA. Jurnal Kajian Bimbingan dan Konseling, 1(1), 12-18. http://dx.doi.org/10.17977/um001v1i12016p012

Hanggara, G. S. (2016). Keefektifan “Proses Guru” Sebagai Teknik Bimbingan Kelompok untuk Meningkatkan Kemampuan. (4), 148-157.

Hartung, P. J., \& Santilli, S. (2018). My Career Story. Journal of Career Assessment, 26(2), 308-321. https://doi.org/10.1177/1069072717692980

Herr, E. L., Cramer, S. H., \& Niles, S. G. (2004). Career guidance and counseling through the lifespan: Systematic approaches (6th ed.). Career Guidance and Counseling through the Lifespan: Systematic Approaches (6th Ed.).

Holland, J. L. (1997). Making Vocational Choices: A Theory of Vocational Personalities and Work Environments. In Englewood Cliffs NJ PrenticeHall. https://doi.org/10.1016/0022-4405(74)90056-9

Marlina, E., Ahmad, M. A., \& Pandang, A. (2015). Pengembangan Inventori Peminatan Karir (IPK) sebagai Alat Ukur Arah Pilih Karir Siswa. Jurnal Penelitian Tindakan Bimbingan \& Konseling, 1(1), 59-64.

Musfirah. (2015). Pengembangan Modul Perencanaan Karier untuk Siswa SMP. Jurnal Psikologi Pendidikan dan Konseling: Jurnal Kajian Psikologi Pendidikan dan Bimbingan Konseling, 1(1), 39-49. https://doi.org/10.26858/jpkk.v1i1.1355

Permendikbud. (2014). 111 Tahun 2014 tentang Bimbingan dan Konseling pada Pendidikan Dasar dan Pendidikan Menengah. Jakarta: Kemendikbud RI. https://doi.org/DOI: 10.1016/j.jconrel.2009.11.021

Putri, S., \& Ramli, M. (2016). Pengembangan Media Permainan Simulasi Ular Tangga Untuk Meningkatkan Tanggung Jawab Belajar Siswa Smp. Jurnal Kajian Bimbingan dan Konseling, 1(2), 40-46. https://doi.org/10.17977/um001v1i12016p040

Sampson, J. P., Hou, P. C., Kronholz, J. F., Dozier, V. C., McClain, M. C., Buzzetta, M., ... Kennelly, E. L. (2014). A content analysis of career development theory, research, and practice - 2013. Career Development Quarterly. https://doi.org/10.1002/j.2161-0045.2014.00085.x

Sampson, J. P., Peterson, G. W., Lenz, J. G., \& Reardon, R. C. (1992). A Cognitive Approach to Career Services: Translating Concepts Into Practice. The Career Development Quarterly. https://doi.org/10.1002/j.2161-0045.1992.tb00360.x

Savickas, M. (2014). Meaning and Mattering in Career Construction: The Case of Elaine. Cannexus. Retrieved from http://cannexus.ca/wp-content/uploads/2014/04/Meaning-and-Mattering-in-Career-Construction-The-Case-of-Elainecx10_Dr.-Savickas_A-Demonstration.pdf

Savickas, M. L. (2013). Career Construction Theory and Practice. In Career Development and Counseling: Putting Theory and Research to Work.

Savickas, M. L., Nota, L., Rossier, J., Dauwalder, J. P., Duarte, M. E., Guichard, J., ... van Vianen, A. E. M. (2009). Life designing: A Paradigm for Career Construction in the 21st Century. Journal of Vocational Behavior, 75(3), $239-250$. https://doi.org/10.1016/j.jvb.2009.04.004

Sharf, R. S. (1992). Applying Career Development Theory to Counseling. Applying Career Development Theory to Counseling.

Sujarwo, S., \& Oktaviana, R. (2017). Pengaruh Warna terhadap Short Term Memory pada Siswa Kelas VIII SMP N 37 Palembang. Psikis: Jurnal Psikologi Islami, 3(1), 33-42. https://doi.org/10.19109/psikis.v3i1.1391

Super, D. E. (1980). A Life-Span, Life-Space Approach to Career Development. Journal of Vocational Behavior, 16(3), 282298. https://doi.org/10.1016/0001-8791(80)90056-1

Yasri, H. L., \& Mulyani, E. (2016). Efektivitas Penggunaan Media Film untuk Meningkatkan Minat dan Hasil Belajar Ekonomi Siswa Kelas X. Harmoni Sosial: Jurnal Pendidikan IPS, 3(1), 138-149. https://doi.org/10.21831/hsjpi.v3i2.7931 